\title{
A Study on the therapeutic ability of gut microbiota upon V. parahaemolyticus infected farm prawn
}

\author{
Nandakumar Rangasamy*1,a , Rajikkannu Muthaiyan ${ }^{1, b}$, \\ Raghu Paramasivam ${ }^{1, \mathrm{c}}$, Deva Arumugam ${ }^{1, \mathrm{~d}}$, Baburajan Radha $^{3, \mathrm{e}}$, \\ Prabhakaran Krishnan ${ }^{2, \mathrm{f}}$ and Masilamni Viveganandan ${ }^{2, \mathrm{~g}}$ \\ ${ }^{1}$ Research Scholar, PG and Research Department of Zoology, Periyar E.V.R College, \\ Tiruchirappalli - 620023, Tamilnadu, India \\ ${ }^{2}$ Assistant Professor, PG and Research Department of Zoology, Periyar E.V.R College, \\ Tiruchirappalli - 620023, Tamilnadu, India \\ ${ }^{3}$ Project Fellow,Department of Immunology, School of Biological Sciences, Madurai Kamaraj \\ University, Madurai-21, Tamilnadu, India \\ ${ }^{*}$ Corresponding Author \\ R. Nandakumar, Research Scholar, PG and Research Department of Zoology, \\ Periyar E.V.R College, Tiruchirappalli- 620023, Tamilnadu, India.

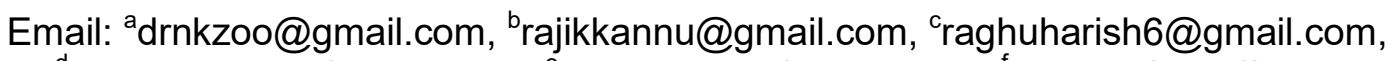 \\ da.devagene23@gmail.com, ebabumkubct@gmail.com, fpkp601@rediff.com \\ and ${ }^{9}$ masila8@reiff.com
}

Keywords: B. coagulans, B. firmus, Amylase activity and gut analysis.

Abstract. Glycogen content of the prawn muscles from the three groups showed increasing trend after 30 days of feed supplementation. In control animals recorded maximum of $2.2 \mathrm{mg} / \mathrm{g}$, and in $B$. coagulans supplemented animals it was $4.1 \mathrm{mg} / \mathrm{g}$ and $3.6 \mathrm{mg} / \mathrm{g}$ in $B$. firmus supplemented animals increase in glycogen content in relation with feed supplementation with probiotic bacteria was most prominent in prawns. The increase in alpha amylases content may be attributed to the influence of the probiotic strain which possess exoenzyme activity. Maximum colonies were found in $B$. firmus supplemented animals gut, 962 cfu after 30 days of feed supplementation. Similar trend was observed in intestinal microflora of all three groups after infection in the feed supplemented animals. The one way analysis of variance showed significant variation among feed supplementation and treatment. The One way analysis revealed that $B$. coagulans supplemented group recorded maximum glycogen followed by $B$. firmus and control groups. Maximum THB count was observed in $B$. firmus supplemented animals after infecting the animals with $V$. parahaemolyticus. Alpha amylase activity was maximum in $B$. firmus supplemented animals was recorded. Significant results could be observed in one way analysis of variance.

\section{INTRODUCTION}

Prawn cultivation is a rapidly expanding industry worldwide especially in Asia. Recently the industry has encountered various disease threats including serious Vibriosis $[1,2]$ and decreased production of Penaeas monodon due to white spot syndrome virus, and severe vibriosis. Probiotics are live micro-organisms, generally bacteria but also yeasts than, when ingested alive in sufficient amount, they have a positive effect on the health going beyond the nutritional ones commonly known. Their use was linked with a proven efficacy on the gut microflora resulted in improved health status. Two main mechanism of action have been suggested and are summarsed as follows: (a) nutritional effect, characterized by reduction of metabolic reactions that produce toxic substances, stimulation of indigenous enzymes and production of vitamins and antimicrobial substances; and (b) health or sanitary effect, distinguished by increase in colonization response [3]; the last effect acting as 'bio-regulators of the gut microflora' and reinforcing the host natural defenses. The probiotics would have therefore a role on the balance of gut microflora increasing the resistance to pathogenic agents, both through a strengthening of the intestinal barrier and stimulating directly the immune system. 
Bacteria that have been used successfully as probiotic belong to the genus Vibrio [4,5], Bacillus spp. [6,7] and Thalasso bacterutilis [8]. Most researchers have isolated these probiotic strains from shrimp culture water $[9,10]$, or from the intestine of different penaeid species [11]. Gomez-Gil et al. [12] demonstrated the existence of a wide diversity of Vibrio species in the hepatopancreas of healthy Penaeus vannamei. The benefits of such supplements include improved feed value, enzymatic contribution to digestion, inhibition of pathogenic microorganisms, antimutagenic and anticarcinogenic activity, growth-promoting factors, and increased immune response [13]. The effect of probiotics for fish and shrimp has been reported [14-18]. In the present study we have evaluated the effect of probiotic bacteria $B$. firmusand $B$. coagulansas feed supplements in the shrimp Penaeusmonodonin normal and Vibrio parahaemolyticusinfected animal and their impact on biochemical parameters such as glycogen, a digestive enzyme, and on the gut microbiota in the laboratory cultured shrimps were evaluated.

\section{MATERIAL AND METHODS}

\section{Experimental design}

Growth experiments were carried out for a period of 60 days in the laboratory. Three replicates were maintained for each treatment. The juvenile shrimps were weighed accurately in a digital electronic balance before the start of the experiment. Post larvae (PL-20) of Penaeus monodon was collected from a farm in Nagapattinam district. Animals were introduced into plastic troughs of 45litre capacity each, filled with 40litre of salinity adjusted sea water. In each plastic trough, 25 animals were maintained. Continuous aeration was given by using compressor air pump to maintain dissolved oxygen at a level of more than $5 \mathrm{ppm}$ in each trough. Water exchange was carried out daily at a rate of $25 \%$ and A pelleted feed based on the recommendations of Tacon [19].

\section{Selection of probiotics and Probiotic Strains}

The probiotic strains were isolated from the gut of wild marine prawns Penaeusmonodonand identified by biochemical tests [20]. Putative probiotic strains of B. coagulansand B. firmus was identified and pure cultures were isolated and mass cultured at $37^{\circ} \mathrm{C}$ for 24 hours in temperature controlled rotary shaker. Bacterial pellets were harvested every 24 hours and stored in a sterile container. Selected strains of probiotics $B$. firmus and $B$. coagulans were mass cultured and the concentration of colony forming units were determined by adjusting the culture to OD -1 . Feed pellets were warmed to $60^{\circ} \mathrm{C}$ and blended with the molten agar containing the bacterial strain $B$. firmus. The mixture was stirred well with sterile glass rods to have a uniform coating of the bacteria over the feed pellets. Similarly, the probiotic cells of B. coagulans were coated on feed pellets, with molten agar. The bacterial content of the coated was approximately $3 \% / \mathrm{w} / \mathrm{w}$. The shrimps were fed with test diets at $5 \%$ of their body weight daily which was split into two rations, one feeding in the morning (9.00-9.30 am) and other in the evening (4.30-5.00 pm). The feed was supplied to the shrimp in the trough by keeping it in a glass plate. Faeces were removed daily before the morning feeding. The survival of the shrimps was observed throughout the experimental period. At the end of growth trial, the final weight of the animal and the dried uneaten feed were taken and used for calculation of growth related parameters.

\section{Biochemical analysis:}

Hepatopancreas, and gut of $P$. monodon, from the various lines of experimental treatments, were analyzed for the biochemical parameters, enzyme alpha amylase, and total heterotrophic bacteria after 30 days of feed supplementation. Glycogen was estimated in the hepatopancreas and muscle of the animal.

\section{Tissue glycogen (Anthrone Method)}

$100 \mathrm{mg}$ of muscle and hepatopancreas was taken and to each of that one $\mathrm{ml}$ of $80 \%$ ethanol was added and centrifuged. The supernatant was collected and $5 \mathrm{ml}$ anthrone reagent was added to the one $\mathrm{ml}$ of the extract. Similarly one $\mathrm{ml}$ of distilled water and one $\mathrm{ml}$ of glucose standard were used 
to prepare the blank and standard respectively. To the blank and standard $5 \mathrm{ml}$ of anthrone reagent was added. The samples were kept in boiling waterbath for 20 minutes and allowed to cool. Then $\mathrm{O}$. D. was read at $620 \mathrm{~nm}$ against the blank and the amount of total free sugar was calculated standard method followed by Roe [21].

\section{Anatomy of the digestive system:}

Anatomical description of the digestive system of Penaeusmonodonis based on the personal observation and guided by the earlier descriptions of prawn digestive system, available in general text books. Midgut or the intestine was a long, narrow straight tube which was not covered internally by the cuticle. Lying along the dorsal median line, between the abdominal flexor and extensor muscles, the midgut extended upto the sixth abdominal segment and bore internal longitudinal folds at the posterior end. The midgut opened into the bulbous hindgut, which was lined by cuticle. The terminal part of the hindgut was tubular and opened to the exterior through the sphinctered anus.

\section{Gut microflora Analysis}

Penaeus monodon from each treatment were taken and washed for few seconds in $0.1 \%(\mathrm{w} / \mathrm{v})$ benzalkonium chloride to remove the bacteria adhering to the exoskeleton and sills. Animals were washed three times in sterile water, after benzalkonium chloride treatment. Animals were cut open aseptically with sterilized instruments. The entire midgut of Penaeus monodon was isolated aseptically and cut open longitudinally, to expose the inner surface. The entire inner surface was scraped into $0.85 \%$ saline and uniformly mixed. The mixture was serially diluted with $0.85 \%$ saline and inoculated on nutrient agar petri plates, and tryptone soya agar plates. Similarly the gut were also scraped and diluted with saline solution. The petriplates were subjected to incubation for 24$48 \mathrm{~h}$. The number of total colonies was counted and their morphology was studied under suitable illumination and magnification. Multiple isolates of colonies of identical morphological features were grown on nutrient agar slants and were stored at $4^{\circ} \mathrm{C}$.

\section{Alpha amylase activity (CNPG3 methodology):}

Amylase occurs in the salivary glands, in pancreas, Alpha amylase is secreted by the pancreas from where it enters the duodenum, through pancreatic duct. 1000ul of working reagent was mixed $25 \mathrm{ul}$ of sample and it was incubated at $37^{\circ} \mathrm{C}$ for one minute, and the change in the absorbance was measured. For every one minute the OD was measured for 3 minutes.

\section{Statistical analysis:}

One way ANOVA of the results were carried out using a statistical package (SPSS version 16).

\section{RESULTS}

\section{Muscles}

Glycogen content of the prawn muscles from the three groups showed increasing trend after 30 days of feed supplementation. In control animals recorded maximum of $2.2 \mathrm{mg} / \mathrm{g}$, and in B. coagulans supplemented animals it was $4.1 \mathrm{mg} / \mathrm{g}$ and $3.6 \mathrm{mg} / \mathrm{g}$ in $B$. firmus supplemented animals (Table 1) increase in glycogen content in relation with feed supplementation with probiotic bacteria was most prominent in prawns. After supplementation the prawns were infected with $V$. parahaemolyticus and its impact on glycogen content was assessed in all three groups. It showed decreasing trend in all three groups but reduction in the glycogen was more than fifty percent with $1 . \mathrm{mg} / \mathrm{g}$ whereas in B. coagulans supplemented animals it was $3.6 \mathrm{mg} / \mathrm{g}$ and in B. firmus supplemented animals 2.9 $\mathrm{mg} / \mathrm{g}$. Analysis of variance revealed that the glycogen variation between the feed groups were statistically significant. One way analysis showed there was significant variation in muscle glycogen content between the three group $B$. coagulans recorded the maximum, but $B$. firmus recorded slightly lower glycogen content, and the control group had the lowest (Table 1). 


\section{Hepatopancreas}

Heapatopancreas showed highest concentration of glycogen, among the tissues estimated. The glycogen content was estimated in prawns from all three groups, uniformly they recorded gain in the glycogen content. The glycogen content was $3.8 \mathrm{mg} / \mathrm{g}$ in control animals, $10.2 \mathrm{mg} / \mathrm{g}$ in $B$. coagualns supplemented animals, and $8.8 \mathrm{mg} / \mathrm{g}$ in B. firmus supplemented animals (Table 2). Similar to that of muscle glycogen in this also there was gradual decrease in glycogen content after infection. Maximum reduction was observed in control animals with $1.4 \mathrm{mg} / \mathrm{g}, 4.5 \mathrm{mg} / \mathrm{g}$ in $B$. coagualns supplemented animals, and $3.5 \mathrm{mg} / \mathrm{g}$ in $B$. firmus supplemented animals. Thus probiotic supplementation has disease combating ability and it was evident that the energy reserve in hepatopancreas in supplemented animal showed near normal level of glycogen. One way analysis of variance showed significant variation among feed supplementation and treatment. One way analysis revealed that $B$. coagulans supplemented animals. There was gradual raise in the hepatosomatic index with duration of feed supplementation. Moreover there was significant difference between the control and probiotic supplemented animals. There was gradual raise in the hepatosomatic index with duration of feed supplementation. Moreover there was significant difference between the control and probiotic supplemented animals. Nearly two fold increase could be observed (Table 3).

\section{Alpha amylase enzyme activity}

After supplementation with live probiotic bacterial strains, B. firmus and B. coagulans there was marked increase in the level of alpha amylase in all the three groups of $P$. monodon in their hepatopacreas. It ranged between $3228.9 \mathrm{U} / \mathrm{I}$ in control animals, $3465.5 \mathrm{U} / \mathrm{I}$ in $B$. coagulans supplemented animals and $3378.8 \mathrm{U} / \mathrm{I}$ in B. firmus supplemented animals in normal animals. In infected animals there was reduction in the enzyme level, it was $1508.8 \mathrm{U} / \mathrm{I}$ in control animals, $2337.4 \mathrm{U} / \mathrm{I}$ in $B$. coagulans supplemented animals and $2237.3 \mathrm{U} / \mathrm{I}$ in B. firmus supplemented animals in normal animals (Table 4). One way ANOVA revealed that there was significant difference based on varied types of feeds used. B. firmus supplemented animal group recorded maximum concentration followed by $B$. firmus supplemented animals and control group (Table 4).The increase in alpha amylases content may be attributed to the influence of the probiotic strain which possess exoenzyme activity (Fig. 1).

\section{Gut microflora analysis}

After the feed supplementation with live probiotic bacterial strains there was marked increase in the total heterotrophic bacterial count, in when compared with that of control. Total heterotrophic bacterial (TNB) count was done two standard media one in nutrient agar and the other in tryptonesoyagar. In both media similar trends of growth were observed. Maximum colonies were found in B. firmus supplemented animals gut, $962 \mathrm{cfu}$ after 30 days of feed supplementation (Table 5). Similar trend was observed in intestinal microflora of all three groups after infection in the feed supplemented animals (Table 6 \& Fig. 3).

\section{DISCUSSION}

Gastrointestinal microbiota of fish and shellfish are dependent on the external environment [22]. The gut is sterile until hatching. Soon after hatching the animal comes in contact with the water and the living and non-living food materials, which leads to successive colonization by a variety of microbes [23-25]. The diversity of this microbiota is influenced by a number of factors including food animal physiology, developmental stages and immunological factors [26]. Digestive enzymes generally act as a barrier for the colonization of bacteria. However those bacteria, which thrive in gut, may be regarded complementary to the establishment and action of digestive enzymes.

Gut microfloral analysis of $P$. monodon revealed that different regions of gut such as foregut, mid gut and hind gut harbour variety of bacteria. Occurrence of bacteria in decapods crustaceans, such as the blue crab Callinectes sapides [27] and M. rosebergii [28] is already known, although these scientists linked this phenomenon to their assumed negative effect on the health of the host. 
Moriarty [29,30] reported the occurrence of bacteria in the gut of penaeid prawns as a normal feature and stressed their beneficial role in the nutrition of the host. Intestine which is lined internally by the endoderm is considered a site not secreting any digestive enzymes, but an organ for passing the waste to the hindgut and a region for second stage absorption of food digested by the hepatopancreas. Intestine's role in digestion may be minor, but cannot be ruled out. The endoderm lining and the mucus in intestine would have provided an ideal niche for the bacteria. In Penaeus monodon, the stomadeum (mouth, pharynx, cardiac and pyloric stomach) and proctodeum (rectum) have internal lining of cuticle, which is sloughed off periodically during moulting. Obviously these areas of the gut can bear only transient microbes and not support a long-term microbiota.

Gram-positive obligate anaerobes are dominant in the gastrointestinal microbiota of man and terrestrial animals [31]. While gram negative facultative anaerobes prevail in the gut of fish and shellfish [32], in P. monodon both gram positive and gram-negative genera were represented.

Administration of Bacillus bacteria to shrimp resulted in an increase in digestive enzyme activity. Gram-positive bacteria, in particular members of the genus Bacillus, do secrete a wide range of exoenzymes [33]. The presence of the probiont may also in some way stimulate endogenous enzymes produced by the shrimp [34]. Flounder (Paralichthysolivaceus) fed a diet containing Chinese herbs had increased pepsin activity in the stomach and protease activity in the intestines [35]. The observed increased specific activity of digestive enzymes may have led to enhanced digestion and absorption of food, which in turn could contribute to the improved growth of $L$. vanamei. In our study, we found amylase activity in both the hepatopancreas and midgut was improved. Because Bacillus bacteria are abundant in the gut, their influence may be more effective. Further work should be conducted to elucidate the mechanism of enhancement of digestive enzyme activity.

The increased activities of digestive enzymes were observed in groups treated with probiotic, $B$. coagulan seven at the latter stages. The shrimp digestive system was activated particularly at the larval and early post-larval stages, when the probiotics would have the greatest effect [36,37]. Moreover, bacteria, particularly members of the genus Bacillus secreted a wide range of exoenzymes $[6,15]$. We could not distinguish between activity due to enzymes synthesized by the shrimp larvae and that due to enzymes synthesized by the probiotic strains colonized in the larvae digestive tract. However, the exogenous enzymes by the probiotic would represent, at most, only a small contribution to the total enzyme activity of the gut $[38,39]$, and the presence of the probiotic might stimulate the production of endogenous enzymes by the shrimp larvae. The observed increased in specific activities of digestive enzymes in probiotic treatments might have led to enhanced digestion and increased absorption of food, which in turn contributed to improved survival in P. vannamei. There was no doubt that the activity of digestive enzyme was influenced by many external and internal factors of the shrimp such as feed and metamorphic changes [40,41]. In the present study also we observed there was characteristic raise in the amylase activity when supplemented with two probiotic species of $B$. firmus and B. coagulans. In the present investigation, a gradual increase in microbial population could be observed in all the gut samples. Although the feed and water may influence the bacterial content of the lumen. Further because of the Bacillus supplements an increase in the gut microflora could also be observed in the present study, with increase in the duration of feed supplementation. However the exoenzymes can play havoc in dead animals. Proteases and lipases produced by bacteria can accelerate the spoilage of marketed prawns [42] and fish [43]. Nevertheless in live condition of the host, beneficial effects of gut microflora far outweigh their deleterious effects. Prebiotics and probiotics can modulate immunity and promote immune boosting effects [44]. The perceived benefits of using immunostimulants in larviculture of aquatic animals are numerous, such as the improvement in welfare, health and production $[45,46]$. 


\section{SUMMARY}

The one way analysis of variance showed significant variation among feed supplementation and treatment. The One way analysis revealed that $B$. coagulans supplemented group recorded maximum glycogen followed by $B$. firmus and control groups. Maximum THB count was observed in $B$. firmus supplemented animals after infecting the animals with $V$. parahaemolyticus. Alpha amylase activity was maximum in B. firmus supplemented animals was recorded. Significant results could be observed in one way analysis of variance.

Table 1 Glycogen content (mg\%) in muscle of normal and $V$. parahamolyticus challenged Penaeus monodon, supplemented with live probiotic $B$. coagulans and B. firmus in (mean $\pm \mathrm{SD}$ )

\begin{tabular}{|c|c|c|c|c|}
\hline S. No & Treatment & Control & B. coagulans & B. firmus \\
\hline 1 & Normal & $2.2 \pm 0.4$ & $4.1 \pm 0.2$ & $3.6 \pm 0.5$ \\
\hline 2 & Infected & $1.1 \pm 0.2$ & $3.6 \pm 0.5$ & $2.9 \pm 0.3$ \\
\hline
\end{tabular}

Table 2 Glycogen content (mg\%) in hepatopancreas of normal and $V$. parahamolyticus challenged Penaeus monodon, supplemented with live probiotic B. coagulans and B. firmusin (mean $\pm \mathrm{SD}$ )

\begin{tabular}{|c|c|c|c|c|}
\hline S. No & Treatment & Control & B. coagulans & B. firmus \\
\hline 1 & Normal & $3.8 \pm 0.3$ & $10.2 \pm 0.4$ & $8.8 \pm 0.4$ \\
\hline 2 & Infected & $1.4 \pm 0.2$ & $4.5 \pm 0.4$ & $3.5 \pm 0.5$ \\
\hline
\end{tabular}

Table 3 Hepatosoatic index of Penaeus monodon, supplemented with live probiotic $B$. firmus and $B$. coagulans

\begin{tabular}{|c|c|c|c|c|}
\hline S. No & $\begin{array}{c}\text { Duration of } \\
\text { feeding }\end{array}$ & Control & B. coagulans & B. firmus \\
\hline 1 & 15 days & 0.08 & 0.15 & 0.1 \\
\hline 2 & 30 days & 0.08 & 0.17 & 0.15 \\
\hline
\end{tabular}

Table 4 Alpha amylase activity in hepatopancreas of normal and $V$. parahamolyticus challenged

Penaeus monodon, supplemented with live probiotic B. coagulans and B. firmus (mean $\pm \mathrm{SD}$ )

\begin{tabular}{|c|c|c|c|c|}
\hline S. No & Treatment & Control & B. coagulans & B. firmus \\
\hline 1 & Normal & $3228.9 \pm 0.9$ & $3465.5 \pm 0.9$ & $3378.8 \pm 0.5$ \\
\hline 2 & Infected & $1508.8 \pm 0.4$ & $2337.4 \pm 0.4$ & $2237.3 \pm 0.8$ \\
\hline
\end{tabular}

Table 5 Gut microflora of Penaeus monodon supplemented with live probiotic $B$. firmus and $B$. coagulans for 30 days

\begin{tabular}{|c|c|c|c|c|}
\hline S. No & Treatments & Dilution & \multicolumn{2}{|c|}{ Number of colony forming units } \\
\hline \multirow[t]{3}{*}{1} & \multirow[t]{3}{*}{ Control } & $10^{\circ}$ & 436 & 620 \\
\hline & & $10^{-1}$ & 356 & 560 \\
\hline & & $10^{-2}$ & 248 & 524 \\
\hline \multirow[t]{3}{*}{2} & \multirow[t]{3}{*}{ B. coagulans } & $10^{-0}$ & 742 & 812 \\
\hline & & $10^{-1}$ & 516 & 720 \\
\hline & & $10^{-2}$ & 386 & 240 \\
\hline \multirow[t]{3}{*}{3} & \multirow[t]{3}{*}{ B. firmus } & $10^{-0}$ & 962 & 788 \\
\hline & & $10^{-1}$ & 686 & 472 \\
\hline & & $10^{-2}$ & 512 & 364 \\
\hline
\end{tabular}


Table 6 Gut microflora of Penaeus monodon supplemented with live probiotic $B$. firmus and $B$. coagulans after infection

\begin{tabular}{|c|c|c|c|c|}
\hline \multirow[b]{2}{*}{ S. No } & \multirow[b]{2}{*}{ Treatments } & \multirow[b]{2}{*}{ Dilution } & \multicolumn{2}{|c|}{ Number of colony forming units } \\
\hline & & & $\begin{array}{c}\text { Tryptone soya } \\
\text { Agar }\end{array}$ & Nutrient Agar \\
\hline \multirow[t]{3}{*}{1} & \multirow{3}{*}{ Control } & $10^{0}$ & 660 & 612 \\
\hline & & $10^{-1}$ & 412 & 540 \\
\hline & & $10^{-2}$ & 348 & 372 \\
\hline \multirow[t]{3}{*}{2} & \multirow{3}{*}{ B. coagulans } & $10^{-0}$ & 856 & 808 \\
\hline & & $10^{-1}$ & 645 & 613 \\
\hline & & $10^{-2}$ & 412 & 372 \\
\hline \multirow[t]{3}{*}{3} & \multirow{3}{*}{ B. firmus } & $10^{-0}$ & 860 & 932 \\
\hline & & $10^{-1}$ & 604 & 728 \\
\hline & & $10^{-2}$ & 324 & 540 \\
\hline
\end{tabular}

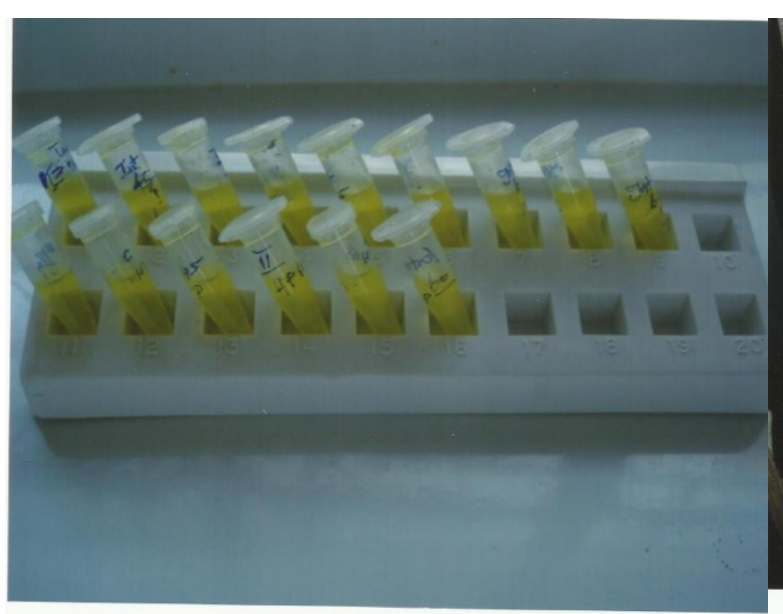

1. Alpha amylase activity in hepatopancreas p.monodon

Fig. 1

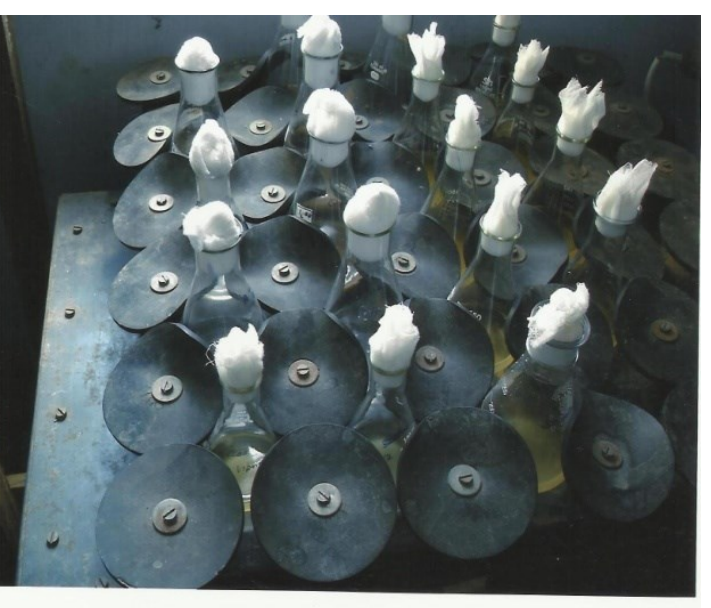

2.Mass culture of bacillus species

Fig. 2

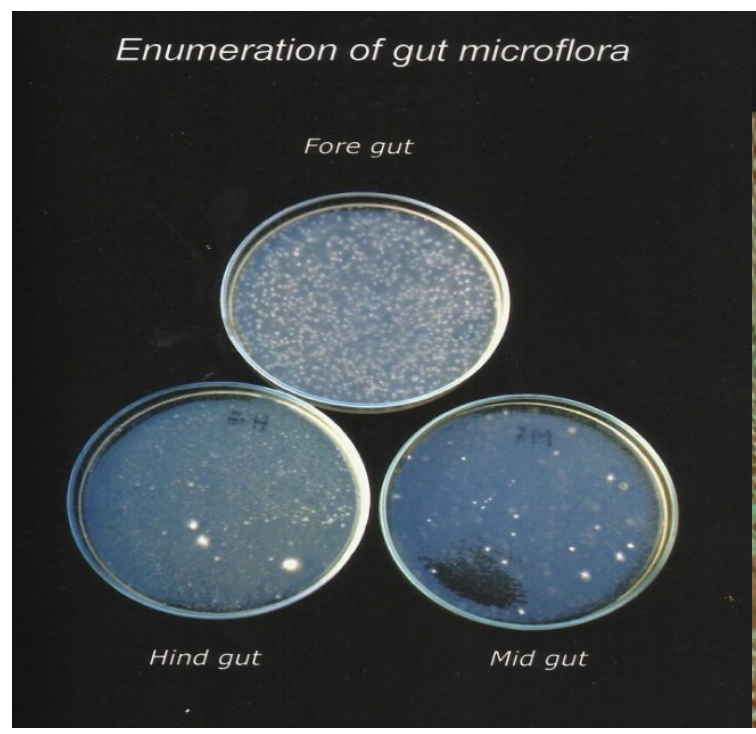

Fig. 3
Pencieus monodon

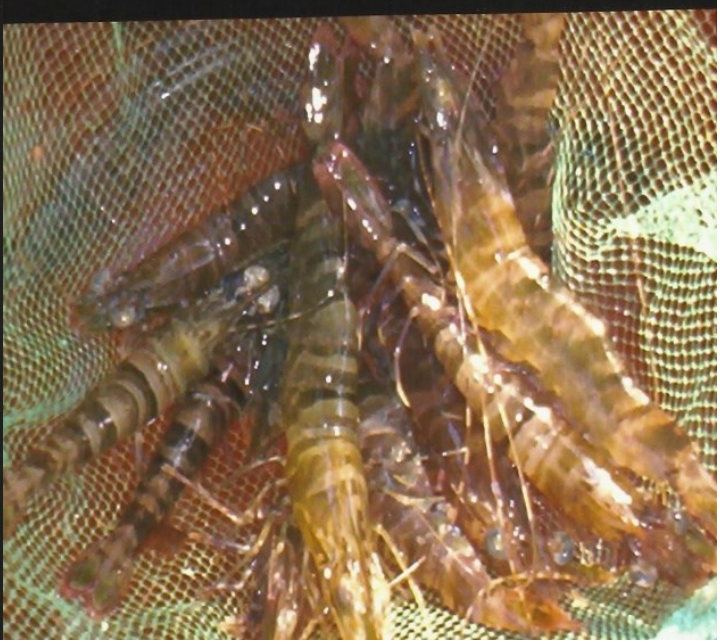

Fig. 4 


\section{REFERENCES}

[1] C.R. Lavilla-Pitogo, C.L. Baticados, E.R. Cruz-Lacierda, L. de la Pena, Occurrence of luminous bacteria disease of Penaeus monodon larvae in the Philippines, Aquaculture, 91 (1990) 1-13.

[2] P. Jirvanichpaisal, T. Miyazaki, Histopathology, Biochemistry and pathogenicity of Vibrio harveyi infecting black tiger shrimp Penaeus monodon, J. Aquat. An. Health. 6 (1994) 27-35.

[3] J.F Guillot, Probiotic feed additives, J. Vet. Pharmacol. Ther. 26 (2003) 52-55.

[4] D.R.W. Griffith, Microbiology and the role of probiotics in Ecuadorian shrimp hatcheries. In: P. Lavens, E. Jaspers, I. Roelants, (Eds.), Larvi' 95-Fish and Shellfish Larviculture Symposium. Special Publications, European Aquaculture Society, Gent, Belgium, 24 (1995) 478.

[5] D. Garriques, G. Arevalo, An evaluation of the production and use of a live bacterial isolate to manipulate the microbial flora in the commercial production of Penaeus vannamei postlarvae in Ecuador. In: Browdy, C.L., Hopkins, J.S. (Ed.), Swimming Through Troubled Water. Proceedings of the Special Session on Shrimp Farming, Aquaculture'95. World Aquaculture Society, Baton Rouge, Louisiana, USA, (1995) 53-59.

[6] D.J.W. Moriarty, Control of luminous Vibrio species in penaeid aquaculture ponds, Aquaculture, 164 (1998) 351-358.

[7] S.W. Rengpipat, S. Phianphak, Piyatiratitivorakul, P. Menasveta, Effects of a probiotic bacterium on black tiger shrimp Penaeus monodon survival and growth, Aquaculture, 167 (1998) 301-313.

[8] M. Maeda, I.C. Liao, Effect of bacterial population on the growth of a prawn larva, Penaeus monodon, Bull. Natl. Res. Inst. Aquac. 21 (1992) 25-29.

[9] K. Nogami, M. Maeda, Bacteria as biocontrol agents for rearing larvae of the Crab Portunustrituber culatus, Can. J. Fish. Aquat. Sci. 49 (1992) 2373-2376.

[10] V. Tanasomwang, T. Nakai, Y. Nishimura, K. Muroga, Vibrio-inhibiting marine bacteria isolated from black tiger shrimp hatchery, Fish. Pathol. 33(5) (1998) 459-466.

[11] S. Rengpipat, S. Rukpratanporn, S. Piyatiratitivorakul, P. Menasaveta, Immunity enhancement in black tiger shrimp (Penaeus monodon) by a probiont bacterium (Bacillus S11), Aquaculture, 191 (2000) 271-288.

[12] B. Gomez-Gil, L. Tron-mayen, A. Roque, J.F. Turnbull, V. Inglis, A.L. Guerra-Flores, Species of Vibrio isolated from hepatopancreas, haemolymph and digestive tract of a population of healthy juvenile Penaeus vannamei, Aquaculture, 163 (1998) 1-9.

[13] L.G. Verschuere, P. Rombaut, W. Sorgeloos, Verstraete, Probiotic bacteria as biological control agents in aquaculture, Microbiol. Mol. Biol. Rev. 64 (4) (2000) 655-671.

[14] S.N. Mohanty, S.K. Swain, S.D. Tripathi, Growth and survival of rohu spawn fed on liver based diet, J. Inland. Fish. Soc. India. 25(2) (1993) 41-45.

[15] P.K Mohanty, S.K. Dash, P.K. Mishra, A.S. Murty, Heat and momentum fluxes over Chilika: a tropical lagoon, Ind. J. Marine Sci. 25 (1996) 184-188.

[16] O.P. Sharma, S.K.S. Bhukhar, Effect of Aquazyn-TM-1000, a probiotic on the water quality and growth of Cyprinus carpio var. communis (L.), Ind. J. Fish. 47(3) (2000) 209-213.

[17] Y.J.H. Wang, R.L. Cheng, Y.Q. Edwards, K.G. He, Z.S. Kong, J.Y. An, M.J. Wu, X.D. Kelly, C.A.D. ykoski, Li, The Holocene Asian Monsoon: Links to solar changes and North Atlantic climate, Science, 308 (2005) 854-857.

[18] Y.B. Wang, Z.R. Xu, Effect of probiotics for common carp (Cyprinus carpio) based on growth performance and digestive enzyme activities. Anim. Feed. Sci. Technol. 127 (2005) 283-292. 
[19] A.G.J. Tacon, Standard methods for the nutrition and feeding of farmed fish and shrimp, Washington DC, Argent Laboratories Press, 1990, pp.454.

[20] P.A West, R.R. Colwell, Identification and classification overview.In R. R. Colwell (ed.), Vibrios in the environment. John Wiley \& Sons, Inc., New York, 1984, pp.285-363.

[21] J.H. Roe, The determination of sugar blood in blood and spinal fluid with anthrone reagent, J. Bio. Chem. 242 (1955) 424-428.

[22] F.J. Gatesoupe, The use of probiotics in aquaculture, Aquaculture, 180 (1999) 147-165.

[23] A.C. Campbell, J.A. Buswell, The intestinal microflora of farmed Dover sole (Solea solea) at different stages of fish development, J. Appl. Bacteriol. 55 (1983) 215-223.

[24] G.H. Hansen, E. Strom, J.A. Olafsen, Effects of deferent holding regimens on the intestinal microflora of herring (Clupeahar engus) larvae, Appl. Environ. Microbiol. 58 (1992) 461-470.

[25] P.D. Munro, A. Barbour, T.H. Birkbeck, Comparison of the gut bacterial flora of start-feeding larval turbot reared under different conditions, J. Appl. Bacteriol. 77 (1994) 560-566.

[26] E. Ringo, T.H. Birkbeck, P.D. Munro, O. Vadstein, K. Hjelmeland, The effect of early exposure to Vibrio pelagius on theaerobic bacterial flora of turbot, Scophthalmus maximus (L.) larvae. J. Applied. Bacteriol. 81 (1996) 207-211.

[27] J.L. Johnson, C.F. Phelps, C.S. Cummins, J. London, F. Gasser, Taxonomy of the Lactobacillus acidophilus group. Int. J. System. Bacteriol. 30 (1980) 53-68.

[28] H.H. Sung, T.Y. Hong, The gram negative bacterial flora in hepato pancreas of giant freshwater prawn (Macrobrachium rosenbergii): antibiotics sensitivities and production of extracellular products. J. Fish. Soc. Taiwan. 24 (1997) 211-223.

[29] D.J.W. Moriarty, Interactions of microorganisms and aquatic animals, particularly the nutritional role of the gut flora.In: (Le'sel R. Ed.), Microbiology in Poecilotherms. Elsevier, Amsterdam, (1990) 217-222.

[30] D.J.W. Moriarty, The role of microorganisms in aquaculture ponds. Aquaculture. 151 (1997) 333-349.

[31] N.J.P. Gournier-Chateau, I. Larpent, J.L. Castellanos, Larpent, Les Probiotics and Alimentation Animal and Human. Technique Documentation Lavoisier, Paris, (1994) 192.

[32] J.D. Clements, Detection of spontaneous synaptic events with an optimally scaled template. Biophys. J. 73(1) (1997) 220-229.

[33] D.J.W. Moriarty, Disease Control in shrimp aquaculture with probiotic bacteria. Micrbial. Inter. Aquaculture. (1996) 1-7.

[34] I.E. Saeed, K. Sopian, Z. ZainolAbidin, Drying kinetics of Roselle (Hibiscus sabdariffa L.): dried in constant temperature and humidity chamber. Proc. SPS 2006.Edited by Muchtar. 29th-30th August. Permata, Bangi, S.D.E., Malaysia: (2006) 143-148.

[35] X.F. Wang, A.S. Auler, R.L. Edwards, H. Cheng, Ito, M. Solheid, Interhemispheric antiphasing of rainfall during the last glacial period, Quat. Sci. Rev. 25 (2006) 3391-3403.

[36] D. Lovett, D. Felder, Ontogenic change in digestive enzyme activity of larval and postlarval white shrimp Penaeus setiferus (Crustacea, Decapoda, Penaeidae). Biol. Bull. 178 (1990) 144-159.

[37] M.S. Kamarudin, D.A. Jones, L. Vay, A.Z. Abidin, Ontogenetic change in digestive enzyme activity during larval development of Macrobrachium rosenbergii. Aquaculture, 123 (1994) 323333.

[38] X. Ding, Z.J. Li, Y.Q. Chen, H.Z. Lin, Y.Y. Yang, K. Yang, Effects of probiotics on growth and activities of digestive enzymes of Penaeus vannamei. J. Fish. Sci. China. 11 (2004) 580-584. 
[39] S. Ziaei-Nejad, M.H. Rezaei, G.A. Takami, D.L. Lovett, A. Mirvaghefi, M. Shakouri, The effect of Bacillus spp. bacteria used as probiotics on digestive enzyme activity, survival and growth in the Indian white shrimp Fenneropenaeus indicus. Aquaculture, 252 (2006) 516-524.

[40] L. Fang, B. Lee, Ontogenic changes in digestive enzymes in Penaeus monodon. Comp. Biochem. Physiol. 103(B) (1992) 1033-1037.

[41] J. Gamboa-Delgado, C. Molina-Poveda, C. Cahu, Digestive enzyme activity and food ingestion in juvenile shrimp Litopenaeus vannamei (Boone, 1931) as a function of body weight, Aquac Res. 34 (2003) 1403-1411.

[42] Rosamma Philip, P. Lakshmanaperumalsamy, Studies on bacterial protease: Time course of growth and protease production at different culture conditions. Fish. Tech. 32(1) (1995) 45-49.

[43] I. Karunasagar, I. Karunasagar, Harvest and post harvest Microbiology of fishes. Ind. J. Microbiol. 31 (1991) 211-229.

[44] G. Reid, The growth potential for dairy probiotics. Inter. Dairy J. 49 (2008) 16-22.

[45] S. Rautava, M. Kalliomaki, M. Isolauri, Probiotics during pregnancy and breastfeeding might confer immunomodulatory protection against atopic disease in the infant. J. Allergy. Clin. Immunol. 109 (2002) 119-121.

[46] M. Viljanen, E. Savilahti, T. Haahtela, K. Juntunen-Backman, R. Korpela, T. Poussa, T. Tuure, M. Kuitunen, Probiotics in the treatment of atopic eczema/dermatitis syndrome in infants: a doubleblind placebo-controlled trial. Allergy. 60(4) (2005) 494-500. 